\title{
Tree Species Composition and Diversity in the Riparian Forest of Lake Barombi Kotto, Cameroon
}

\author{
Awo Miranda Egbe ${ }^{*}{ }^{\circledR}$, Pascal Tabi Tabot ${ }^{2}$, Fonge Beatrice Ambo ${ }^{1}$ \\ ${ }^{1}$ Department of Plant Science, University of Buea, Buea, Cameroon \\ ${ }^{2}$ Department of Agriculture, Higher Technical Teachers' Training College Kumba, University of Buea, Buea, Cameroon \\ Email: *awomiranda1@gmail.com, ttabot@yahoo.com, ambofonge@yahoo.com
}

How to cite this paper: Miranda Egbe, A., Tabot, P.T. and Ambo, F.B. (2021) Tree Species Composition and Diversity in the Riparian Forest of Lake Barombi Kotto, Cameroon. American Journal of Plant Sciences, $12,127-145$

https://doi.org/10.4236/ajps.2021.121008

Received: November 16, 2020

Accepted: January 25, 2021

Published: January 28, 2021

Copyright ( 2021 by author(s) and Scientific Research Publishing Inc. This work is licensed under the Creative Commons Attribution International License (CC BY 4.0).

http://creativecommons.org/licenses/by/4.0/

\begin{abstract}
Tree species composition and diversity were investigated in the riparian forest around Lake Barombi Kotto, Cameroon. This study aimed at determining the tree species composition, population structure, and providing evidence of anthropogenic disturbances in the riparian forest of Lake Barombi Kotto. The objectives were to determine the tree species composition and diversity in the riparian forest around Lake Barombi Kotto, to elucidate the forest structure and to document the anthropogenic disturbances in this forest. Five plots were laid within which the tree enumeration and measurement of dbh were carried out. Trees were identified using scientific identification keys in the Flora of West Africa. Disturbance scores were given to each site by qualitatively assessing various disturbances. A total of 340 trees belonging to 70 plant species, 63 genera and 28 plant families were enumerated. Shannon-Wiener diversity varied across sites, with the highest value $(\mathrm{H}=3.45)$ recorded in Tung and the lowest $(\mathrm{H}=2.21)$ in Malenda. Population structure differed across sites, the largest stand basal area of $43.78 \mathrm{~m}^{2} /$ ha was recorded in Bondokombo while the smallest $\left(2.15 \mathrm{~m}^{2} / \mathrm{ha}\right)$ was recorded in the Sacred Island. Cecropia peltata L., Pseudospondias macrocarpa Oliv. Pierre and Ceiba pentandra (L.) Gaertn had the largest basal areas across the different sites. Species rich families were Malvaceae ( 9 species), Fabaceae ( 9 species), Annonaceae (4 species), and Anacardiaceae (4). This study shows that, there is a high tree species diversity in the protected forest (Tung) but the other unprotected sites are highly disturbed by anthropogenic activities. There is need to develop and enhance existing management policies for this riparian forest, especially by replanting the cut trees and creating a protected riparian buffer to conserve its floristic diversity and ecological functions.
\end{abstract}




\section{Keywords}

Riparian Forest, Tree Dynamics, Importance Value Index, Lake Barombi Kotto

\section{Introduction}

All over the world, land-water ecotones are characterized by a high biodiversity compared to their adjacent ecosystems, usually as a result of the heterogeneous habitats created by frequent disturbances [1] [2]. Occurring at a transition zone between the terrestrial uplands and aquatic ecosystems, these ecotones are highly productive and provide a habitat for a large range of co-existing plant and animal species [3]. Riparian areas have become an integral part of watershed management in different landscapes and because of the many ecosystem services they render, they are undergoing serious degradation as a result of anthropogenic pressure [4]. Hence there is need to pay more attention to these areas to ensure that, the key ecosystem functions and services they render are not hampered. Riparian vegetation encompasses a wide range of plant life forms ranging from herbs, shrubs, climbers and lianas to trees. Trees and other woody plants that form the dense canopies are recognized as the primary and most valuable components of riparian communities [5]. Riparian vegetation is denser, taller and in most cases has different species and more diverse composition than the adjacent upland terrestrial ecosystems. This can be partly explained by greater water availability (higher soil moisture) and their unique soils which are frequently disturbed [6]. The multi-layered vegetation structure dominated by moisture-loving (hydrophilic) trees, shrubs and herbs, forms a distinctive physiognomy in the landscape [2].

Forests are a source of livelihood to most rural communities especially in developing countries, satisfying local demands for fuel wood, construction material, herbs for medicinal uses including socioeconomic functions alongside their key ecological functions like carbon sequestration, mediation of biogeochemical cycles, water table stabilization, water retention and filtration, prevention of bank erosion and also serving as a habitat for fauna [7] [8] [9].

Differences in biogeography, habitat type and disturbances have resulted to variations in tree diversity along different landscapes, with the major types of disturbances grouped into natural and anthropogenic [10]. The natural perturbations in riparian landscapes include wind action, fire, action of water amongst others while anthropogenic activities include logging of riparian trees, livestock grazing, conversion of forest to agricultural lands and construction of dams and houses [1] [11]. Both forms of perturbations are known to have tremendous effects on the forest vegetation structure, causing compositional and structural changes in riparian plant community structure and soil characteristics. This usually results to deforestation and land degradation [5] [12] [13].

Degradation of riparian vegetation is a serious problem and studies have 
proven that, this is mostly as a result of increased land use activities around these forests [14] [15] [16]. These changes most often are characterized by a decline in biological diversity, tree basal area, and tree canopy cover. Processes that lead to the removal of leaf litter, soil compaction, a reduction in native species diversity and a concomitant increase in the abundance and diversity of exotic plant species are usually associated to riparian degradation [17] [18]. As a result, riparian ecosystems are considered as potentially threatened and endangered ecosystems in the world [14]. Hence, the distribution characteristics of the vegetation, the relationship between plant diversity and the major influencing factors of plant diversity in the riparian vegetation should be understood to solve vegetation restoration and management problems in these areas. Several studies have been carried out to elucidate the floristic composition and anthropogenic disturbances within riparian ecosystems. Reference [18] determined the impact of land use on riparian forest along urban and rural gradient in the southeastern ecozone of Canada and found that agricultural land use tremendously affected species composition and soil quality. Loss of native species and a proliferation of exotic plants with reduced ecosystem services were associated to high anthropogenic disturbances in Southern India [19].

Among the Congo basin countries, Cameroon has the fourth largest amount of dense tropical forest with around $42 \%$ of its total land area covered with forest [20]. Cameroon also has an estimated annual deforestation rate range of $0.06 \%-$ $0.2 \%$, placing it among the highest in the Congo basin countries. The former dense riparian forest around Lake Barombi Kotto is facing a high anthropogenic pressure from wood extractors who use wood for the construction of houses, canoes, fuel wood for cooking and drying of cocoa [7]. This has led to structural simplification of the riparian vegetation and the probable disappearance of some keystone animal and plant species. Some portions of the forest are intensively cultivated for different agricultural purposes, exposing the soil to erosion and siltation with the resultant effect of leaching of some organic debris and agrochemicals directly into Lake Barombi Kotto. These various land uses may have profound ecological implications on the lake's ecological integrity.

Detailed knowledge about the ecology, floristic composition and diversity of plant communities which is the first step to conservation is still lacking in the riparian forest of Lake Barombi Kotto. A rapid inventory of tree species provides information on abundance and diversity which are useful tools in plant conservation. In order to formulate policies governing species decline and to control ecological drivers of change, it is important to identify the status of species present in the forest, whether they are rare, endangered, abundant or getting extinct. This study therefore aims at giving an account of the general tree structure in terms basal area, species composition, similarity between different fragments of the riparian forest and the evidence of anthropogenic disturbances within this forest.

The objectives of this study were 
1) to determine the tree species composition, abundance and diversity in the riparian forest around Lake Barombi Kotto.

2) to delimit the forest structure in terms of tree basal area and determine the Importance Value Index (IVI) of the different tree species.

3) to provide evidence on the different anthropogenic activities carried out in this forest.

\section{Materials and Methods}

\subsection{Description of Study Area}

The riparian forest describes the stretch of natural forest that surrounds Lake Barombi Kotto, a shallow fresh water crater lake located $100 \mathrm{~m}$ above sea level in a complex geological arrangement of volcanic rocks. It is found between latitude $4^{\circ} 27^{\prime} 49.3^{\prime \prime} \mathrm{N}$ and $4^{\circ} 28^{\prime} 29.2^{\prime \prime} \mathrm{N}$, and longitude $9^{\circ} 15^{\prime} 56.1^{\prime \prime} \mathrm{E}$ and $9^{\circ} 15^{\prime} 36.4^{\prime \prime} \mathrm{E}$ in Meme Division of the South West Region, Cameroon [21]. The continuous and adequate availability of both ground and shallow water table around the Lake Barombi Kotto allows the establishment and long-term existence of different plant species, thus justifying their classification as riparian vegetation (Figure 1). Immediately after this natural forest are large plantations of Cocoa (Theobroma cacao L.) and small subsistence agricultural farms where food crops are cultivated. Barombi Kotto has a tropical climate, a long rainy season (March-October) and a Dry season (November-February). Annual temperature is $25.5^{\circ} \mathrm{C}$ and annual rainfall is $3035 \mathrm{~mm}$ with the driest month being January which has $45 \mathrm{~mm}$ of rainfall [22].

\subsection{Tree Composition and Diversity Analysis}

A reconnaissance survey was carried out in November to delimit sampling plots and nature of the vegetation. A total number of four plots measuring $250 \mathrm{~m}$ by $40 \mathrm{~m}$ were laid in Tung, Komba, Malenda and Bondokombo, and within each, four quadrats of 50 by $40 \mathrm{~m}$ were laid. These quadrats were located at fixed distances, each separated from the other by $10 \mathrm{~m}$ intervals. An additional plot was laid in the Sacred Island of Kotto Barombi called Fionda Fiond which is an isolated Island with no anthropogenic influences due to its location and sacred nature. GPS coordinates of each of these sites were collected using Garmin etrex and descriptions of each plot were noted (Table 1).

All individual trees with diameter at breast height $(\mathrm{dbh}) \geq 10 \mathrm{~cm}$ were counted and identified within each plot. The dbh $(1.3 \mathrm{~m})$ of the species were measured using a diameter tape. In the case of buttresses, the measurement was made above the buttress, following standard forestry techniques. Trees were identified using scientific identification keys in the Flora of West Africa. This was done together with experienced taxonomists of the Limbe Botanical Garden. Voucher specimens were collected in triplicates for unidentified species and taken to the Limbe Botanical Garden for identification. The present dataset was updated to match the APG III classification of angiosperm families [23]. 


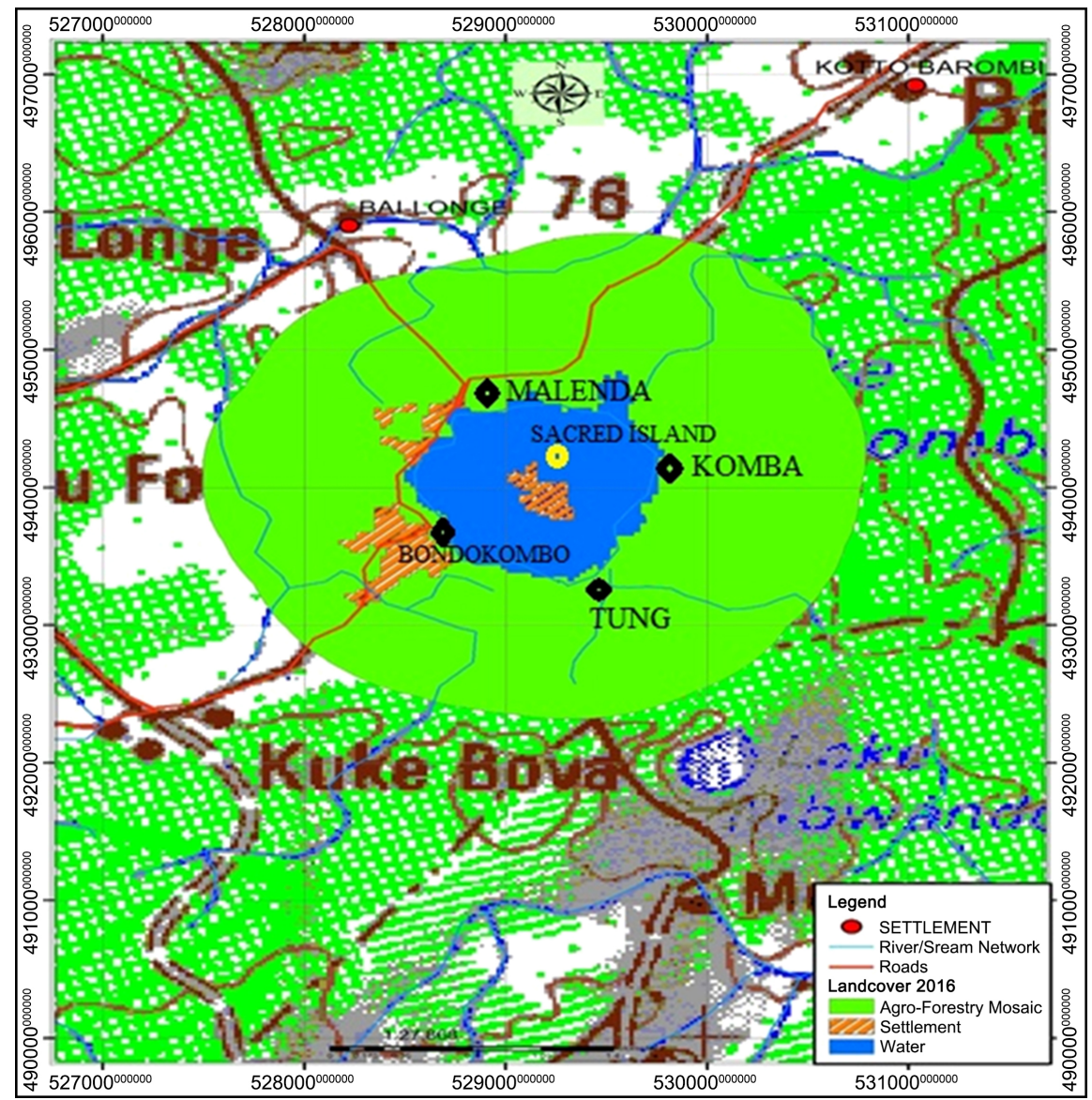

Figure 1. Riparian vegetation showing study sites and other land cover types around Lake Barombi Kotto, Cameroon.

Table 1. Description of sampling plots in riparian forest of Lake Barombi Kotto.

\begin{tabular}{|c|c|c|c|c|c|}
\hline \multirow{2}{*}{ Site } & \multirow{2}{*}{ Site Name } & \multicolumn{3}{|c|}{ GPS Coordinates } & \multirow{2}{*}{ Description } \\
\hline & & Latitude & Longitude & Elevation (m) & \\
\hline Sacred Island & Fionda fiond & $04^{\circ} 28^{\prime} 18.1^{\prime \prime N}$ & $009^{\circ} 15^{\prime} 48.1^{\prime \prime} \mathrm{E}$ & 99 & $\begin{array}{l}\text { Isolated Island within Lake Barombi } \\
\text { Kotto, characterized by a thick } \\
\text { vegetation (Control site) }\end{array}$ \\
\hline Plot 1 & Tung & $04^{\circ} 27^{\prime} 49.3^{\prime \prime} \mathrm{N}$ & $009^{\circ} 15^{\prime} 56.1^{\prime \prime E}$ & 123 & $\begin{array}{l}\text { Adjacent to a waterfall and an inflowing } \\
\text { stream. Protected by the Barombi } \\
\text { Traditional Council. }\end{array}$ \\
\hline Plot 2 & Komba & $04^{\circ} 27^{\prime} 58.0^{\prime \prime} \mathrm{N}$ & $009^{\circ} 16^{\prime} 00.2^{\prime \prime} \mathrm{E}$ & 103 & $\begin{array}{l}\text { Forest adjacent to Tung, leading to } \\
\text { large cocoa farms. }\end{array}$ \\
\hline Plot 3 & Malenda & $04^{\circ} 28^{\prime} 29.2^{\prime \prime} \mathrm{N}$ & $009^{\circ} 15^{\prime} 51.8^{\prime \prime} \mathrm{E}$ & 109 & $\begin{array}{l}\text { Located on the upper left wing of } \\
\text { Lake Barombi, bordered by } \\
\text { large cocoa farms. }\end{array}$ \\
\hline Plot 4 & Bondokombo & $04^{\circ} 28^{\prime} 29.2^{\prime \prime} \mathrm{N}$ & $009^{\circ} 15^{\prime} 36.4^{\prime \prime} \mathrm{E}$ & 106 & $\begin{array}{l}\text { Adjacent to non-native settlement, } \\
\text { located on the lower left wing of } \\
\text { Lake Barombi Kotto. }\end{array}$ \\
\hline
\end{tabular}


With respect to the evidence of anthropogenic activities in the riparian forest, observations were made within the study sites and disturbance scores obtained for each site as described by [24]. Disturbance scores were given to each site by qualitatively assessing various disturbances (tree logging, grazing, fire occurrence, encroachment and settlement) which were ranked into rare (1), occasional (2) and frequent (3) levels of disturbances. At the end, the sum of all the scores within each site was calculated and sites with high values were considered as high disturbance sites while those with low values as low disturbance sites.

\subsection{Data Analysis}

Data were analyzed using standard methods relevant to the different ecological parameters outlined below.

\section{Ecological Measurements}

The vegetation data were quantitatively analyzed for basal area, relative density, relative frequency and relative dominance. Importance Value Index (IVI) for the tree species was determined as the sum of the relative frequency, relative density and relative dominance [25].

Basal area $\left(\mathbf{m}^{2}\right)=\pi(1 / 2 \mathrm{dbh})^{2}$

Density $=$ Total number of individuals of species in all the quadrats /

Total number of quadrats studied

Relative density $=($ Total number of individuals of species $/$

Total number of individuals of all species $) \times 100$

Relative frequency $=($ Total number of quadrats in which species occurred $/$ total number of quadrats studied $) \times 100$

Relative dominance $=($ Total basal area of species $/$

$$
\text { total basal area of all species }) \times 100
$$

Importance Value Index $($ IVI $)=\Sigma$ relative density + relative frequency

$$
+ \text { relative dominance }
$$

\section{Diversity indices}

Shannon-Wiener Index was used to determine the tree diversity, calculated as follows:

$$
\mathrm{H}^{\prime}=-\sum(\mathrm{ni} / \mathrm{N}) \ln (\mathrm{ni} / \mathrm{N}) \quad[26]
$$

where $\mathrm{H}=$ Index of species diversity, $P i=$ Proportion of total sample belonging to $i$ th species, $n=$ number of species, $\ln =$ natural $\log$.

Pielou's Eveness Index [27]

$$
\mathrm{E}=\mathrm{H}^{\prime} / \ln (\mathrm{S})
$$

where $\mathrm{H}^{\prime}$ is the Shannon Index of species diversity and $\ln S$ is the natural $\log$ of the total number of species.

SØrenson's similarity index [28] 


$$
\mathrm{Cj}=2 \mathrm{C} / \mathrm{a}+\mathrm{b}
$$

where $C$ is the number of species common to both sites, (a) is the number of species in site $\mathrm{A}$ and $\mathrm{b}$ is the number of species in site $\mathrm{B}$.

\section{Results}

\subsection{Riparian Forest Structure and Species Composition}

A total of 340 individual trees were enumerated in the floristic survey. These trees belong to 70 species, 61 genera and 28 plant families. Results of some ecological parameters recorded during the survey are presented in Table 2.

The highest number of tree species was recorded in Tung, 44 species from 36 genera and 22 families and the least number of species was recorded in Malenda (13 species from 13 genera and 11 families). In Komba, a total of 25 species from 24 genera and 16 plant families were recorded while in Bondokombo, a total of 37 tree species from 34 genera and 18 plant families were recorded. The Sacred Island had 14 tree species from 14 genera and 12 families. The Shannon-Wiener diversity differed across the different sites, with the highest diversity recorded in Tung $(\mathrm{H}=3.58)$ and the least in Malenda (2.21). The Stand basal area differed across the different forest sites. The highest stand Basal area occurred in Bondokombo with a value of $43.78 \mathrm{~m}^{2} \cdot \mathrm{ha}^{-1}$ and the lowest was found in Malenda $\left(5.81 \mathrm{~m}^{2} / \mathrm{ha}\right)$.

\subsubsection{Site Similarity}

SØrenson's Index of Similarity expresses the similarity between communities and it gives a value between 0 and 1 . The closer the value is to 1 , the more the similarities communities have in common. Complete community overlap is equal to 1 ; complete community dissimilarity is equal to 0 . In this study, the highest SØrenson's coefficient was found between Komba and Bondokombo (0.47) and the lowest was between Tung and Bondokombo (0.28). A very close similarity was found between the tree species in the Sacred Island other sites in the study (Table 3).

Table 2. Some ecological parameters of the riparian forest around Lake Barombi Kotto, Cameroon.

\begin{tabular}{cccccc}
\hline Parameter & Tung & Komba & Malenda & Bondokombo & Sacred Island \\
\hline Number of species & 44 & 25 & 13 & 37 & 14 \\
Number of genera & 36 & 24 & 13 & 34 & 14 \\
Number of families & 22 & 16 & 11 & 18 & 12 \\
Shannon-Wiener Index & 3.58 & 2.99 & 2.21 & 3.26 & 2.45 \\
$\quad$ Pielou's Eveness & 0.92 & 0.92 & 0.86 & 0.9 & 0.92 \\
Stand Basal area $\left(\mathrm{m}^{2} \cdot \mathrm{ha}^{-1}\right)$ & 17.84 & 11.93 & 5.81 & 43.78 & 2.15 \\
\hline
\end{tabular}




\subsubsection{Relative Abundances of Families}

The twenty-eight plant families encountered during the study had varying relative abundances and number of species within the different surveyed plots. A total of twenty two plant families were recorded in Tung, eighteen in Bondokombo, sixteen in Komba, eleven in Malenda and twelve in the Sacred Island. The families with the highest number of species were Malvaceae ( 9 species), Moraceae (4), Fabaceae (3) and Meliaceae (3). The following plant families were among the most abundant families in the riparian forest: Malvaceae (19.71\%), Anacardiaceae (11.76\%), Moraceae (10.88\%), Meliaceae (8.53\%), and Fabaceae (7.35\%). The least abundant families were Dracaenaceae (0.59\%), Putrajivaceae (0.59\%), Flacourtiaceae $(0.59 \%)$, Rubiaceae $(0.59 \%)$, Violaceae $(0.59 \%)$, Ulmaceae $(0.59 \%)$, Rhamnaceae $(0.29 \%)$, Burseraceae $(0.29 \%)$ and Verbenaceae $(0.29)$ (Figure 2). The most abundant plant species in the riparian forest were Pseudospondias macrocarpa (8.52) Cecropia peltata (6.17) Ceiba pentandra (5.0) Trichilia rubescens (4.70) Ficus sur (4.11).

Table 3. SØrenson's Similarity Index across study sites in the riparian forest around Lake Barombi Kotto, Cameroon.

\begin{tabular}{ccccc}
\hline & Tung & Komba & Malenda & Bondokombo \\
\hline Tung & - & & & \\
Komba & 0.28 & - & & \\
Malenda & 0.35 & 0.41 & - & - \\
Bondokombo & 0.25 & 0.47 & 0.34 & 0.58 \\
Sacred Island & 0.28 & 0.6 & 0.59 & \\
\hline
\end{tabular}

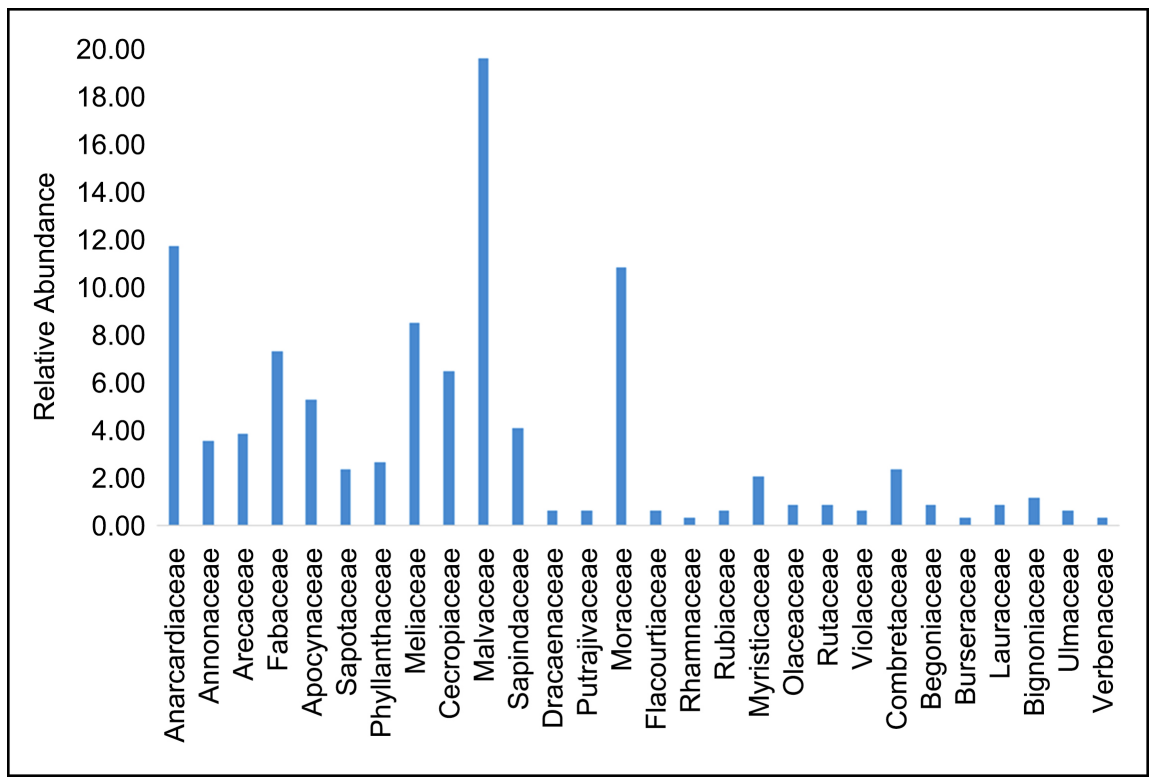

Figure 2. Relative abundance of plant families in the riparian forest of Lake Barombi Kotto, Cameroon. 
Of the twenty two families in Tung, Malvaceae, Moraceae, Meliaceae, Apocynaceae and Cecropiaceae had the highest relative abundances $(15.62 \%, 10.93 \%$, $10.51 \%, 10.1 \%$ and $9.37 \%$ respectively) while the least abundant families were Dracaenaceae $(0.78 \%)$, Rhamnaceae $(0.78 \%)$ and Rubiaceae $(0.78 \%)$. In Komba, a total of 16 plant families were recorded. The highest relative abundances were recorded in Fabaceae (16\%), Anacardiaceae (14\%), Apocynaceae (14\%), Malvaceae (14\%), Meliaceae (12\%) and Moraceae (8\%) while the families with the least relative abundances included Arecaceae, Benoniaceae, Burseraceae, Combretaceae, Dracaenaceae, Myristicaceae and Phyllanthaceae which all had a relative abundance of $2 \%$. The highest number of species in this forest fragment was recorded in Malvaceae (4), Fabaceae (3) and Moraceae (3). Of the eleven plant families recorded in Malenda, the Anacardiaceae had the highest relative abundance $(32.14 \%)$. This was followed by Malvaceae and Meliaceae which had relative abundances of $17.86 \%$ and $14.29 \%$ respectively. Malvaceae and Meliaceae had the highest number of species ( 2 species each) for this site. A total number of eighteen plant families were recorded in Bondokombo with four plant families having the highest relative abundances (Malvaceae: 30.27\%, Moraceae: 13.76\%, Anacardiaceae: $10.09 \%$ and Fabaceae: $10.09 \%$ ). The highest number of species were found in Fabaceae (6), Moraceae (6), Annonaceae (4) and Malvaceae (4) while Anacardiaceae (28\%) and Arecaceae (20\%) were the families with the highest abundances in the Sacred Island.

\subsubsection{Basal Area}

Table 4 shows the first five tree species with the largest basal areas in each riparian forest fragment during the study. In Tung, tree basal area ranged from 0.01 - $3.35 \mathrm{~m}^{2} /$ ha. The top five species with the largest basal areas included Cecropia peltata (3.35 $\mathrm{m}^{2} / \mathrm{ha}$ : Cecropiaceae), Pseudospondias macrocarpa $\left(2.48 \mathrm{~m}^{2} / \mathrm{ha}\right.$ : Anacardiaceae), Ceiba pentandra (1.42 $\mathrm{m}^{2} /$ ha: Malvaceae), Chytranthus talbotii (1.28 $\mathrm{m}^{2} /$ ha: Sapindaceae) and Tabermontana crassa $\left(1.23 \mathrm{~m}^{2} /\right.$ ha: Apocynaceae). In Komba, tree basal area ranged from $0.01-7.20 \mathrm{~m}^{2} /$ ha. Pseudospondias macrocarpa (Anacardiaceae), Ceiba pentandra (Malvaceae), Albizia zygia (Fabaceae), Aningeria robusta (Sapotaceae) and Trilepidium angolensis (Moraceae) were the tree species with the largest basal areas $\left(7.2 \mathrm{~m}^{2} / \mathrm{ha}, 1.14 \mathrm{~m}^{2} / \mathrm{ha}, 0.96\right.$ $\mathrm{m}^{2} /$ ha, $0.66 \mathrm{~m}^{2} /$ ha and $0.47 \mathrm{~m}^{2} /$ ha respectively). In Malenda, tree basal area ranged from 0.01 - $4.35 \mathrm{~m}^{2} /$ ha with Pseudospondias macrocarpa (Anacardiaceae), Sterculia tragacantha (Malvaceae), Cola lateritia (Malvaceae), Trichilia rubescens (Meliaceae) and Cleistopholis patens (Annonaceae) being the species with the largest basal areas $\left(4.35 \mathrm{~m}^{2} / \mathrm{ha}, 0.67 \mathrm{~m}^{2} / \mathrm{ha}, 0.28 \mathrm{~m}^{2} / \mathrm{ha}, 0.11 \mathrm{~m}^{2} / \mathrm{ha}\right.$ and $0.10 \mathrm{~m}^{2} /$ ha respectively). Tree basal area in Bondokombo ranged from 0.01 $24.15 \mathrm{~m}^{2} /$ ha. Ceiba pentandra (Malvaceae), Sterculia oblonga (Malvaceae), Ficus mucuso (Moraceae), Lannea welwischii (Anacardiaceae) and Pseudospondias macrocarpa (Anacardiaceae) were among the tree species with the largest basal areas $\left(24.15 \mathrm{~m}^{2} / \mathrm{ha}, 7.87 \mathrm{~m}^{2} / \mathrm{ha}, 2.88 \mathrm{~m}^{2} / \mathrm{ha}, 1.92 \mathrm{~m}^{2} /\right.$ ha and $1.08 \mathrm{~m}^{2} /$ ha respectively). 
Table 4. Tree species with highest Basal area $(B A)\left(\mathrm{m}^{2}\right)$ in the riparian forest of Lake Barombi Kotto, Cameroon.

\begin{tabular}{|c|c|c|c|c|c|c|c|c|c|c|}
\hline \multirow{2}{*}{$\mathrm{S} / \mathrm{N}$} & \multicolumn{2}{|l|}{ TUNG } & \multicolumn{2}{|l|}{ KOMBA } & \multicolumn{2}{|l|}{ MALENDA } & \multicolumn{2}{|c|}{ BONDOKOMBO } & \multicolumn{2}{|c|}{ SACRED ISLAND } \\
\hline & SPECIES & BA & SPECIES & BA & SPECIES & BA & SPECIES & BA & SPECIES & BA \\
\hline 1 & $\begin{array}{l}\text { Cecropia } \\
\text { peltata L. }\end{array}$ & 3.35 & $\begin{array}{c}\text { Pseudospondias } \\
\text { macrocarpa } \\
\text { (Oliv) Pierre }\end{array}$ & 7.20 & $\begin{array}{c}\text { Carapa grandifolia } \\
\text { Sprague }\end{array}$ & 4.35 & $\begin{array}{l}\text { Ceiba pentandra } \\
\text { (L.) Gaertn }\end{array}$ & 24.15 & $\begin{array}{l}\text { Elaeis guineensis } \\
\text { Jacq. }\end{array}$ & 0.91 \\
\hline 2 & $\begin{array}{c}\text { Pseudospondias } \\
\text { macrocarpa } \\
\text { (Oliv) Pierre }\end{array}$ & 2.48 & $\begin{array}{l}\text { Ceiba pentandra } \\
\text { (L.) Gaertn }\end{array}$ & 1.14 & $\begin{array}{l}\text { Sterculia } \\
\text { tragacantha } \\
\text { Lindl }\end{array}$ & 0.67 & $\begin{array}{c}\text { Sterculia oblonga } \\
\text { Mast. }\end{array}$ & 7.87 & $\begin{array}{l}\text { Mangifera } \\
\text { indica L }\end{array}$ & 0.47 \\
\hline 3 & $\begin{array}{l}\text { Ceiba pentandra } \\
\text { (L.) Gaertn }\end{array}$ & 1.42 & $\begin{array}{c}\text { Albizia zygia } \\
\text { (DC.) J.F. Macbr }\end{array}$ & 0.96 & $\begin{array}{l}\text { Cola lateritia } \\
\text { K.Schum }\end{array}$ & 0.28 & $\begin{array}{c}\text { Ficus mucuso } \\
\text { Welw.ex Ficalho }\end{array}$ & 2.88 & $\begin{array}{l}\text { Alstonia boonei } \\
\text { De Wild }\end{array}$ & 0.16 \\
\hline 4 & $\begin{array}{c}\text { Chytranthus } \\
\text { talbotii (Baker f.) } \\
\text { Keay }\end{array}$ & 1.28 & $\begin{array}{l}\text { Aningeria robusta } \\
\text { (A.Chev.) Aubrev } \\
\text { \& Pellegr }\end{array}$ & 0.66 & $\begin{array}{c}\text { Trichilia } \\
\text { rubescens Oliv. }\end{array}$ & 0.11 & $\begin{array}{c}\text { Lannea welwischii } \\
\text { Hiern Engl }\end{array}$ & 1.92 & $\begin{array}{l}\text { Lannea welwitschii } \\
\text { Hiern Engl. }\end{array}$ & 0.16 \\
\hline 5 & $\begin{array}{l}\text { Tabernaemontana } \\
\text { crassa Benth. }\end{array}$ & 1.23 & $\begin{array}{l}\text { Trilepidium } \\
\text { angolensis } \\
\text { Ficalho }\end{array}$ & 0.47 & $\begin{array}{l}\text { Cleistopholis } \\
\text { patens Benth } \\
\text { Engl \& Diels }\end{array}$ & 0.10 & $\begin{array}{l}\text { Pseudospondias } \\
\text { macrocarpa } \\
\text { Oliv. Pierre }\end{array}$ & 1.08 & $\begin{array}{l}\text { Sterculia } \\
\text { tragacantha } \\
\quad \text { Lindl }\end{array}$ & 0.15 \\
\hline
\end{tabular}

The basal area of trees in the Sacred Island ranged from $0.01-0.91 \mathrm{~m}^{2} / \mathrm{ha}$. Elaies guineensis Jacq. (Arecaceae), Mangifera indica L. (Anacardiaceae), Alstonia boonei Wild (Apocynaceae) and Lannea welwischii Hiern Engl (Anacardiaceae) were among the tree species with the largest basal areas $\left(0.91 \mathrm{~m}^{2} / \mathrm{ha}, 0.47\right.$ $\mathrm{m}^{2} / \mathrm{ha}, 0.16 \mathrm{~m}^{2} / \mathrm{ha}, 0.10 \mathrm{~m}^{2} / \mathrm{ha}$ and $0.15 \mathrm{~m}^{2} /$ ha respectively).

\subsubsection{Importance Value Index (IVI)}

Trees in the different plots of the riparian forest differed in terms of IVI (Table 5). In Tung, IVI ranged from $2.05-29.84$. The species with the highest IVI included: Cecropia peltata (IVI of 29.84), Pseudospondias macrocarpa (IVI of 21.52), Tabernaemontana crassa (IVI of 17.2), Chytranthus talbotii (IVI of 15.54) and Ficus sur (IVI of 14.67). In Komba, tree species with the highest IVI included the following: Pseudospondias macrocarpa (IVI of 80.06), Albizia zygia (IVI of 23.79), Aningeria robusta (IVI of 17.23), Trichilia rubescens (IVI of 15.06) and Ceiba pentandra (IVI of 14.41). IVI in Malenda ranged from 10.38 120.4. Trees with the highest IVI were Pseudospondias macrocarpa (IVI of 120), Sterculia tragacantha (IVI of 39.18), Trichilia rubescens (IVI of 19.29), Ficus sur (IVI of 15.22) and Cola lateritia (IVI of 14.67). The IVI of trees in Bondokombo ranged from 2.90 - 69.96, with the highest IVI in Ceiba pentandra (IVI of 69.96), Sterculia oblonga (IVI of 31.07), Ficus mucuso (IVI of 14.18), Lannea welwischii (IVI of 12.89) and Cecropia peltata (IVI of 11.39). In the Sacred Island, Elaies guineensis, Mangifera indica, Alstonia boonei, Sterculia tragacantha and Pseudospondias macrocarpa were the five most important species with IVI values of $69.21,44.95,22.65,21.65,21.94$ and 19.70 respectively. 
Table 5. List of 5 tree species with highest Importance value index (IVI) in the riparian forest of Lake Barombi Kotto, Cameroon.

\begin{tabular}{|c|c|c|c|c|c|c|c|c|c|c|}
\hline \multirow{2}{*}{$S / N$} & \multicolumn{2}{|l|}{ TUNG } & \multicolumn{2}{|l|}{ KOMBA } & \multicolumn{2}{|l|}{ MALENDA } & \multicolumn{2}{|c|}{ BONDOKOMBO } & \multicolumn{2}{|c|}{ SACRED ISLAND } \\
\hline & SPECIES & IVI & SPECIES & IVI & SPECIES & IVI & SPECIES & IVI & SPECIES & IVI \\
\hline 1 & $\begin{array}{l}\text { Cecropia } \\
\text { peltata } \mathrm{L} .\end{array}$ & 29.84 & $\begin{array}{l}\text { Pseudospondias } \\
\text { microcarpa } \\
\text { (Oliv) Pierre }\end{array}$ & 80.06 & $\begin{array}{l}\text { Pseudospondias } \\
\text { macrocarpa } \\
\text { Oliv. Pierre }\end{array}$ & 120 & $\begin{array}{l}\text { Ceiba pentandra } \\
\text { (L.) Gaertn }\end{array}$ & 69.96 & $\begin{array}{l}\text { Elaeis guineensis } \\
\text { Jacq. }\end{array}$ & 69.21 \\
\hline 2 & $\begin{array}{c}\text { Pseudospondias } \\
\text { macrocarpa } \\
\text { (Oliv) Pierre }\end{array}$ & 21.52 & $\begin{array}{l}\text { Albizia zygia } \\
\text { (DC.) J.F. Macbr }\end{array}$ & 23.79 & $\begin{array}{l}\text { Sterculia } \\
\text { tragacantha } \\
\text { Lindl }\end{array}$ & 39.18 & $\begin{array}{c}\text { Sterculia oblonga } \\
\text { Mast. }\end{array}$ & 31.07 & $\begin{array}{l}\text { Mangifera } \\
\text { indica } \mathrm{L}\end{array}$ & 44.95 \\
\hline 3 & $\begin{array}{l}\text { Tabernaemontana } \\
\text { crassa Benth. }\end{array}$ & 17.2 & $\begin{array}{c}\text { Aningeria robusta } \\
\text { (A.Chev.) Aubrev } \\
\text { \& Pellegr }\end{array}$ & 17.23 & $\begin{array}{c}\text { Trichilia rubescens } \\
\text { Oliv. }\end{array}$ & 19.29 & $\begin{array}{l}\text { Ficus mucuso } \\
\text { Welw.ex Ficalho }\end{array}$ & 14.18 & $\begin{array}{l}\text { Alstonia boonei } \\
\text { De Wild }\end{array}$ & 22.65 \\
\hline 4 & $\begin{array}{c}\text { Chytranthus } \\
\text { talbotii (Baker f.) } \\
\text { Keay }\end{array}$ & 15.54 & $\begin{array}{c}\text { Trichilia } \\
\text { rubescens } \text { Oliv. }\end{array}$ & 15.06 & Ficus sur Forssk & 15.22 & $\begin{array}{c}\text { Lannea welwischii } \\
\text { Hiern Engl }\end{array}$ & 12.89 & $\begin{array}{l}\text { Sterculia } \\
\text { tragacantha } \\
\text { Lindl }\end{array}$ & 22.71 \\
\hline 5 & Ficus sur Forssk & 14.67 & $\begin{array}{l}\text { Ceiba pentandra } \\
\text { (L.) Gaertn }\end{array}$ & 14.14 & $\begin{array}{l}\text { Cola lateritia } \\
\text { K.Schum. }\end{array}$ & 14.67 & $\begin{array}{l}\text { Cecropia } \\
\text { peltata L. }\end{array}$ & 11.39 & $\begin{array}{c}\text { Pseudospondias } \\
\text { microcarpa } \\
\text { (Oliv) Pierre }\end{array}$ & 19.70 \\
\hline
\end{tabular}

Overall, the most important species in terms of IVI in the riparian forest of Lake Barombi Kotto were Ceiba pentandra (IVI = 33.64), Pseudospondias macrocarpa $(\mathrm{IVI}=23.25)$, Sterculia oblonga $(\mathrm{IVI}=14.70)$, Cecropia peltata $(\mathrm{IVI}=$ 12.49 ) and Sterculia tragacantha (IVI $=10.12)$ while the most important plant families were Malvaceae (IVI $=76.55)$, Anacardiaceae (IVI $=35.43)$, Moraceae $(\mathrm{IVI}=31.50)$, Fabaceae $(\mathrm{IVI}=22.32)$ and Meliaceae $(\mathrm{IVI}=19.48)$. Those with the least IVI included Violaceae (1.56), Verbenaceae (1.19), Burseraceae (1.10), Putrajivaceae (1.09) and Rhamnaceae (1.09).

\subsection{Evidence of Anthropogenic Disturbances in the Riparian Forest}

Results of anthropogenic disturbances recorded during the study are presented on Table 6. These disturbances included grazing, fire, encroachment by agricultural farms, tree logging, and construction of houses (settlement). Bondokombo, Malenda and Komba had a total score of nine, seven and four respectively and were classified as sites with high disturbance while Tung a total score of one, and thus classified as low disturbance. No anthropogenic disturbance was recorded in the Sacred Island.

\section{Discussion}

\subsection{Forest Structure and Species Composition}

A total of 70 tree plant species were recorded in the survey, belonging to 28 plant families and 61 genera. The most species-rich families were Malvaceae, Fabaceae, 
Table 6. Disturbance score $(1=$ low, 2 = moderate; 3 = high $)$ for five study sites in the riparian forest of Lake Barombi Kotto, Cameroon.

\begin{tabular}{cccccc}
\hline Disturbance & Tung & Komba & Malenda & Bondokombo & Sacred Island \\
\hline Grazing & 0 & 0 & 0 & 2 & 0 \\
Fire & 0 & 0 & 1 & 1 & 0 \\
Settlement & 0 & 0 & 0 & 2 & 0 \\
Encroachment & 0 & 2 & 3 & 1 & 0 \\
Tree logging & 1 & 2 & 3 & 3 & 0 \\
Total score & 1 & 4 & 7 & 9 & 0 \\
\hline
\end{tabular}

Annonaceae, Moraceae and Anacardiaceae. Several studies have documented high diversities of these plant families in different forests including riparian ecotones. [13] documented a high diversity of Fabaceae, Moraceae and Meliaceae at Upper, Middle and Lower zones of Dikhu river, in India. Similar findings were made by [4] in the forest reserve around Lake Barombi Mbo, Cameroon where high diversities of Fabaceae, Moraceae, Malvaceae were recorded. Reference [29] also recorded high diversities of Moraceae, Meliaceae and Fabaceae in the Takamanda forest, Southwest Cameroon. Same observations were made by [30] who also recorded high species richness in Annonaceae and Fabaceae in Dja forest reserve in Cameroon. Fabaceae has been found to be the most species rich family in most forest formations. This is further confirmed by [31] who reported that Fabaceae is the most dominant plant family in the tropics and in Neotropical lowlands. The species richness of these families can be attributed to their good seed dispersal mechanisms which make them to be capable of colonizing different forest fragments, coupled with their ability to produce numerous seeds which eventually establish at suitable sites. The high number of specialists in Tung forest than in other forest fragments indicates that some of the indigenous species of this riparian forest are conserved in this site. Tung is the water recharge zone of Lake Barombi Kotto, the inflowing stream (Tung Nsuria) which feeds Lake Barombi Kotto flows through this forest. The Barombi Kotto community depends on it for the supply of potable water. As a result of this very important role, the Barombi Kotto traditional Council has put in place laws prohibiting logging activities in this zone. This therefore explains why Tung forest had the highest tree diversity. Ficus sur was one of the generalist species in this study. Species of Ficus (Moraceae) have been documented as common tree species in riparian landscapes [32]. They are prominent components of riparian zones where they contribute to bank stability, supporting associated animals. Three different species of Ficus were recorded in this study: Ficus exasperata, F. mucosus and $F$. sur. These findings are in line with [32] who studied the distribution and abundance of riparian Ficus in Nothern Thailand and reported sev- 
eral Ficus species as common riparian trees. Some are capable of growing on rocks (rheophytes) while other species grow on bankside as specialists. Generalists found in this riparian forest provide main food resource by producing fruits all year round which sustain the frugivore population especially when other fruits are limited in supply. Hence the diversity of these trees has relevance for conservation and also maintenance of the integrity of this unique ecosystem.

\subsection{Shannon Diversity and IVI}

The Shannon-Wiener diversity index which takes into account the total number of species and their relative abundance offers a good description of communities and allows comparisons to be made between them. The high Shannon diversity $(\mathrm{H}=3.7)$ recorded in the riparian forest of Lake Barombi Kotto indicates a high floristic heterogeneity with a high number of native plant species. Low diversity of riparian tree species in Malenda could be attributed to the severity of observed land use activities like logging, agricultural land conversion carried out in this forest. These findings are similar to those of [33] who studied the effects of different land uses in a riparian landscape in Kenya. Disturbance parameters like garbage, number and size of foot trails and presence or absence of logging in forest sites were used to determine the associations between these variables and species richness and composition. They recorded low tree diversities in urban sites and corresponding poor soil characteristics in areas of high land use activities.

The high species diversity in Tung could be due to the fact that this forest is protected by the Barombi Kotto traditional council which prohibits logging and other anthropogenic activities in this forest. This high diversity can be explained by the fact that most of the trees are within the diameter class of $10-30 \mathrm{~cm}$, their canopies are not large and this permits more light levels to penetrate the forest floor, influencing the growth and establishment of seedlings of a wide number of species. The presence of a water fall and a shallow stream that run across this forest offer a unique microclimate that is suitable for the growth and regeneration of the tree species in this forest. A very low diversity was recorded in the Sacred Island. This could be due to the fact that this Island is isolated from the other sites and is surrounded by the lake which prevents the transfer and movement of seeds and some pollinators. It was dominated by palms (Elaies guineensis) whose seeds can be dispersed by water and birds capable of flying for long distances.

With respect to the SØrenson's coefficient, all the different forest fragments had similar species, implying that the forest's floristic diversity was homogeneous. IVI is introduced as a one of the most important indices in forest management and the index can be useful in biodiversity preservation [34]. The high values of IVI recorded by Ceiba pentandra (IVI = 33.64), Pseudospondias macrocarpa $(\mathrm{IVI}=23.25)$, Sterculia oblonga $(\mathrm{IVI}=14.70)$, Cecropia peltata $(\mathrm{IVI}=12.49)$ 
and Sterculia tragacantha $(\mathrm{IVI}=10.12)$ suggest that these plants make the greatest contribution in this riparian forest in terms of relative frequencies of occurrence, relative abundances and relative dominance. Malvaceae, Anacardiaceae, Moraceae and Meliaceae were among the most important families in this study suggesting their influence in the functioning of the riparian forest of Lake Barombi Kotto. Similar findings were made by [31] in the riparian forest of Benin. These families were also recorded among others in protected riparian areas in Togo [11].

\subsection{Evidence of Anthropogenic Alterations}

Anthropogenic activities recorded within this forest included grazing, fire, encroachment, tree logging and settlement. These activities have been categorized as drivers of change in riparian landscapes, responsible for the structural simplification, loss of biodiversity and a reduction in the generation of ecosystem services by riparian forests [14] [19].

Tung a total score of one, and thus classified as low disturbance. There was the absence of disturbances like grazing, fire, encroachment of agricultural farms and settlement in this site and tree logging was rare in the site. This could be due to the fact that this site is protected by the Barombi Kotto traditional council, owing to the fact that it is harbours the inflowing stream that feeds Lake Barombi Kotto and it is the only source of potable water in this community. No anthropogenic disturbance was recorded in the Sacred Island probably as a result of its sacred nature and mythical beliefs about its existence and most importantly by virtue of its enclosed nature.

Bondokombo, Malenda and Komba had very high disturbance scores and were classified as highly disturbed sites. The high disturbance score of Bondokombo could be due to its proximity to the non-native settlement, and also because the main beach into the Barombi Kotto Island settlement is found in this site, thus exposing it to a high anthropogenic pressure. Malenda was also subjected to almost the same pressure but no form of settlement was recorded in this site. The very frequent tree logging in Malenda and Bondokombo, coupled with the encroachment of agricultural farms, mostly cocoa farms could lead to the exposure of bare soil and subsequent soil erosion. Tree logging and encroachment of agricultural farms have been considered as the main activities associated with the deterioration of the water quality of Barombi Kotto [7].

Increased sedimentation in this lake could be as a result of soil erosion aggravated by tree logging, fire and other disturbances recorded during the study. The removal of streamside vegetation not only removes the binding effects of roots upon the soil, but also causes a reduction in the hydraulic roughness of the bank and an increase in flow velocities near the bank [35]. Such situations invariably lead to accelerated channel erosion during subsequent periods of high flow or even during episodes of high rainfall. This may further be exacerbated 
by environmental changes such as climate change.

Although the degradation of native riparian plant communities by unsustainable logging, agriculture, and grazing can often be reversed, other practices such as drainage modifications and structural developments in these areas generally lead to irreversible changes in riparian areas over long periods of time e.g. some parts of the forest in Bondokombo had settlement very close to it, land was cleared for the pinning of electrical poles. The impacts of these anthropogenic alterations are manifested in the water quality of adjacent water bodies.

\section{Conclusions}

This study has assessed the floristic composition of trees as well as species diversity in the riparian forest of Lake Barombi Kotto, thus providing a first checklist of the trees found in the riparian forest. This study reveals that the riparian forest harbors a rich tree species composition, which provides habitat and food resources to a large dependent community of fauna. A high tree diversity $(\mathrm{H}=3.7)$ was recorded in the riparian forest of Lake Barombi Kotto indicating a high floristic heterogeneity with a total of 70 tree species belonging to 28 plant families and 61 genera. The most species-rich families were Malvaceae, Fabaceae, Annonaceae, Moraceae and Anacardiaceae.

The stand basal area of trees in the riparian forest of Lake Barombi Kotto ranged from 5.81 to $43.7 \mathrm{~m}^{2} / \mathrm{ha}$., with Cecropia peltata L., Pseudospondias macrocarpa Oliv. Pierre, Ceiba pentandra (L.) Gaertn having the highest basal areas across the different forests. Trees in the different plots of the riparian forest also differed in terms of IVI. The most important species in the riparian forest of Lake Barombi Kotto were Ceiba pentandra, Pseudospondias macrocarpa, Sterculia oblonga, Cecropia peltata and Sterculia tragacantha. Five most important plant families in terms of IVI were Malvaceae, Anacardiaceae, Moraceae, Fabaceae, Meliaceae.

Anthropogenic activities are direct drivers of change in this ecosystem. These anthropogenic disturbances were grazing, fire, encroachment, tree logging and settlement. Bondokombo and Malenda and Komba had very high disturbance scores and classified as highly disturbed sites. The Sacred forest and Tung had little or no anthropogenic disturbances.

Prevailing anthropogenic activities like tree logging for construction of houses and canoes, fuel wood collection and forest conversion to agricultural farmlands by the locals have imposed a huge threat to the survival of this ecologically-sensitive landscape. If nothing is done to curb the current trends of anthropogenic pressure, plant recruitment, growth and development shall be affected with long term effects of local extinction of some species and total disappearance of the riparian forest. Traditional authorities have the potentials of managing forest resources and preserving both the resources and ecological integrity. This was seen in the Tung forest which was protected by the tradi- 
tional council because it is the water recharge zone which feeds both Lake Barombi Kotto and also provides them with potable water. The resultant effect of this was a high tree diversity compared to the other unprotected forest fragments.

Therefore, a proper conservation and management strategy is required for this forest to ensure sustainability. Reforesting of the already destroyed portions of the forest with the indigenous plants within this forest is vital. This is important in maintaining and safeguarding the key ecosystem functions and services of this forest and also preserving its integrity. There is a need for environmental education of both the inhabitants of the Barombi Kotto Island community and other users of these forest resources on the importance of riparian vegetation, its management and conservation.

\section{Recommendations for Further Studies}

Further studies should be carried out to determine the carbon stock in this forest. Other life forms including herbs, shrubs and animal population of this forest should be studied so that the forest dynamics can be fully understood. There is a need for an ethno-botanical study to establish the relationship between this vegetation and man. This information can be useful in pharmaceutical industries as well as policy development towards management of the forest. The effects of anthropogenic activities on the soil characteristics should be studied especially as this could influence the growth and development of the riparian vegetation as well as the water quality of Lake Barombi Kotto.

\section{Acknowledgements}

We are very grateful to the Traditional Council Barombi of Kotto for accepting that this study be carried out even in the protected and sacred forests of Barombi Kotto community.

\section{Declaration of Conflict of Interests}

No potential conflict of interest was declared by the authors.

\section{References}

[1] Shekhar, R.B., Azim, U.M., Nicholas, T.B. and Prity, L.B. (2019) Effects of Disturbance Type and Microhabitat on Species and Functional Diversity Relationship in Stream Bank Plant Communities. Forest Ecology and Management, 432, 812-822. https://doi.org/10.1016/j.foreco.2018.10.021

[2] Leo, M., Juan, A., Francisco, L., Ricardo, G. and Nagore, G. (2019) Drivers of Plant Richness Patterns of Mediterranean Riparian Forests at Local and Regional Scales Have Bottom-Up and Top Down Effects. Journal of Vegetational Science, 30, 485-497. https://doi.org/10.1111/jvs.12728

[3] Petrakis, R.E., Willem, J.D., Villarreal, M.L., Tashjian, P., Russo, R.D. and Scott, C.A. (2017) Historical Analysis of Riparian Vegetation Change in Response to Shifting Management Objectives on the Middle Rio Grande. Land, 6, 29. 
https://doi.org/10.3390/land6020029

[4] Fonge, B.A., Tabot, P.T., Bakia, M.A. and Che, C.A. (2019) Patterns of Land-Use Change and Current Vegetation Status in Peri-Urban Forest Reserves: The Case of the Barombi Mbo Forest Reserve, Cameroon. Geology, Ecology, and Landscapes, 3, 104-113. https://doi.org/10.1080/24749508.2018.1508981

[5] Ding, Y., et al. (2019) Functional Features of Tropical Montane Rainforests along a Logging Intensity Gradient. Ecological Indicators, 97, 311-318. https://doi.org/10.1016/j.ecolind.2018.10.030

[6] Zaimes, G.N., Schultz, R.C. and Isenhart, T.M. (2006) Riparian Land Uses and Precipitation Influences on Stream Bank Erosion in Central Iowa. Journal of American Water Resource, 42, 83-97. https://doi.org/10.1111/j.1752-1688.2006.tb03825.x

[7] Awo, M.E., Fonge, B.A. and Tabot, P.T. (2019) Ecosystem Services and Perception of Water Quality of Lake Barombi Kotto, Cameroon. International Journal of Trends in Scientific Research \& Development, 3, 1739-1746. https://doi.org/10.31142/ijtsrd23529

[8] Krzeminska, D., Tjibbe, K., Skaalsveen, K. and Stotte, J. (2019) Effects of Riparian Vegetation on Stream Bank Stability in Small Agricultural Catchments. Catena, 172, 87-96. https://doi.org/10.1016/j.catena.2018.08.014

[9] Dybala, K.E., Matzek, V., Gardali, T. and Seavy, N.E. (2019) Carbon Sequestration in Riparian Forests: A Global Synthesis and Meta-Analysis. Global Change Biology, 25, 57-67. https://doi.org/10.1111/gcb.14475

[10] Xi, W., Peet, R.K., Lee, M.T. and Urban, D.L. (2019) Hurricane Disturbances, Tree Diversity and Succession in North Carolina Piedmont Forests, USA. Journal of For est Research, 30, 219-231. https://doi.org/10.1007/s11676-018-0813-4

[11] Fousseni, F., Marra, D., Wala, K., et al. (2014) Basic Overview of Riparian Forest in Sudanian Savanna Ecosystem: Case Study of Togo. Review Écologique (Terre Vie), 69, 24-38.

[12] Ngole-Jeme, V.M., Fonge, B.A., Tabot, P.T. and Mumbang, C. (2016) Impact of Logging Activities in a Tropical Mangrove on Ecosystem Diversity and Sediment Heavy Metal Concentrations. Journal of Coastal Conservation, 20, 245-255. https://doi.org/10.1007/s11852-016-0435-y

[13] Leishangthem, D. and Singh, M.R. (2018) Tree Diversity, Distribution and Population Structure of a Riparian Forest from Certain Zones along the Dikhu River in Nagaland, India. Journal of Forestry and Environmental Science, 34, 31-45.

[14] Natta, A.K., Sinsin, B. and van der Maesen, L.J. (2002) Riparian Forests, a Unique But Endangered Ecosystem in Benin. Botanische Jahrbucher, 124, 55-69. https://doi.org/10.1127/0006-8152/2002/0124-0055

[15] Wood, E.C., Tappan, G.G. and Hadj, A. (2003) Understanding the Drivers of Agricultural Land Use Change in South-Central Senegal. Journal of Arid Environments, 59, 565. https://doi.org/10.1016/j.jaridenv.2004.03.022

[16] Cooper, S.D., Lake, P.S., Sabater, S., Melack, J.M. and Sabo, J.L. (2013) The Effects of Land Use Changes on Streams and Rivers in Mediterranean Climates. Hydrobiologia, 719, 383-425. https://doi.org/10.1007/s10750-012-1333-4

[17] Gregory, H.W. and Naiman, R.J. (2000) Vulnerability of Riparian Zones to Invasion by Exotic Vascular Plants. Plant Ecology, 148, 105-114. https://doi.org/10.1023/A:1009800327334

[18] Moffatt, S.F., McLachlan, S.M. and Kenkel, N.C. (2004) Impacts of Land Use on Riparian Forest along an Urban Rural Gradient in Southern Manitoba. Plant Ecology, 
174, 119-135. https://doi.org/10.1023/B:VEGE.0000046055.27285.fd

[19] Sunil, C., Somashekar, R.K. and Nagaraja, B.C. (2011) Impact of Anthropogenic Disturbances on Riparian Forest Ecology and Ecosystem Services in Southern India. International Journal of Biodiversity Science, Ecosystem Services and Management, 7, 273-282. https://doi.org/10.1080/21513732.2011.631939

[20] Bikie, H., Jean-Gael, C., Djomo, L., Minnemeyer, S., Ngoufo, R. and Nguiffo, S. (2000) An Overview of Logging in Cameroon: A Global Forest Watch Report. World Resource Institute, Washington DC.

[21] Awo, M.E., Tabot, P.T., Nso, G. and Fonge, B.A. (2018) Spatiotemporal Variation of Phytoplankton Community Structure in the Crater Lake Barombi Kotto, Cameroon. International Journal of Current. Research in Biological Science \& Plant Biology, 5, 36-55. https://doi.org/10.20546/ijcrbp.2018.502.005

[22] Greer, G.J., Mimpfoundi, R., Malek, E.A., Joky, A., Ngonseu, E. and Ratard, R.C. (1990) Human Schistosomiasis in Cameroon. II. Distribution of the Snails Hosts. American Journal of Tropical Medicine and Hygiene, 42, 573-780.

https://doi.org/10.4269/ajtmh.1990.42.573

[23] APG III (2009) The Angiosperm Phylogeny Group. An Update of the Angiosperm Phylogeny Group Classification for the Orders and Families of Flowering Plants. Botanical Journal of Linean Society, 161, 105-121. https://doi.org/10.1111/j.1095-8339.2009.00996.x

[24] Mani, S. and Parthasarathy, N. (2006) Tree Diversity and Structure in Inland and Coastal Tropical Dry Evergreen Forests of Peninsular India. Current Science, 90, 1238-1246.

[25] Armstrong, A.H., Shugart, H.H. and Fatoyinbo, T.E. (2011) Characterization of Community Composition and Forest Structure in a Madagascar Lowland Rainforest. Tropical Conservational Science, 4, 428-444. https://doi.org/10.1177/194008291100400406

[26] Shannon, C.E. and Wiener, W. (1963) The Mathematical Theory of Communication. University of Illinois Press, Urbane.

[27] Pielou, E.C. (2014) Diversity Indices.

[28] SØrenson, T. (1948) A Method of Establishing Groups of Equal Amplitude in Plant Sociology Based on Similarity of Species and Its Application to Analyses of the Danish Commons. Biologiske Skrifter/Kongelige Danske Videnskabernes Selskab, 5, $1-34$.

[29] Ndah, N.R., Egbe, E.A. and Eneke, B. (2013) Species Composition, Diversity and Distribution in a Disturbed Takamanda Rainforest, South West, Cameroon. African Journal of Plant Science, 7, 577-585. https://doi.org/10.5897/AJPS2013.1107

[30] Djuikouo, M.K., Doucet, J., Nguembou, C.K., Lewis, S.L. and Sonke, B. (2016) Diversity and Aboveground Biomass in Three Tropical Forest Types in the Dja Biosphere Reserve, Cameroon. African Journal of Ecology, 48, 1053-1063. https://doi.org/10.1111/j.1365-2028.2010.01212.x

[31] Natta, A.K. (2003) Ecological Assessment of Riparian Ecosystems in Benin: Phytodiversity, Phytophysiology and Spatial Distribution of Species. PhD Thesis, Wageningen University, Wageningen.

[32] Pornwiwan, P., Compton, S.G. and Wangpakapattanawong, P. (2014) Riparian Ficus Tree Communities: The Distribution and Abundance of Riparian Fig Trees in Northern Thailand. PLOS ONE, 9, e108945.

https://doi.org/10.1371/journal.pone.0108945 
[33] Njue, N., Koech, E., Hitimana, J. and Sirmah, P. (2016) Influence of Land Use Activities on Riparian Vegetation, Soil and Water Quality: An Indicator of Biodiversity Loss, South West Mau Forest, Kenya. Open Journal of Forestry, 6, 373-385. https://doi.org/10.4236/ojf.2016.65030

[34] Timilsina, N., Ross, M.S. and Heinen, J.T. (2007) A Community Analysis of Sal (Shorea robusta) Forests in the Western Terai of Nepal. Forest Ecology and Management, 241, 223-234. https://doi.org/10.1016/j.foreco.2007.01.012

[35] NRC (National Research Council) (2002) Riparian Areas: Functions and Strategies for Management. National Academy Press, Washington DC. 